\title{
Effects of flaxseed oil supplementation to lactating goats diet on milk production, composition and fatty acids profiles
}

\author{
M. A. Ali ${ }^{1,}{ }^{*}$, M. Sh. Thabet ${ }^{1}$ and E. M. Ibrahim ${ }^{2}$
}

${ }^{1}$ Dairy Department, Faculty of Agriculture, Al-Azhar University, Cairo, Egypt

2 Sheep and Goats Research Department, Animal Production Research Institute, Agriculture Research Center, Giza, Egypt

*Corresponding author E-mail: DR.Mansourabdou@azhar.edu.eg (M. Ali).

\begin{abstract}
Milk goats is of particular nutritional and economic importance in many parts of the world. This study aimed to define the effect of quaffing dairy goats with linseed oil (10, 20 and 30 $\mathrm{mL} /$ head/day) on milk production composition and fatty acids profile. Twenty-four lactating Zaraibi goats at the last weeks of gestation were used. Experimental animals were randomly divided into four equal groups. Result obtained revealed that flaxseed oil supplementation increased milk yield by a mean value of $19.79 \%$ as compared with control treatment. Milk fat percentage was higher for goats received $30 \mathrm{~mL}$. flaxseed oil than other treatments, while no remarkable effect of flaxseed oil supplementation on milk protein, lactose and ash contents was detected. Addition of flaxseed oil to goats' diet resulted in reducing saturated fatty acids by a mean value of $13.72 \%$ as compared with control sample, however, these decreases may be influenced partially by lactation progress. In contrast, the concentration of unsaturated fatty acids increased with a mean value of $28.32 \%$, with pronounced increases in oleic, linoleic and linolenic acids concentration as compared with control. Moreover, results obtained revealed that $\alpha$-linolenic acid (ALA) concentrations achieved greatly affect by flaxseed oil supplementation, where their concentrations varied from $0.2-3.04 \%$. In conclusion, feeding flaxseed to lactating goats can be used as a nutritional strategy to reduce concentrations of short-chain and saturated fatty acids and to increasing long-chain and polyunsaturated fatty acids in milk, as well as to improve milk yield. Consequently, such strategy has a significant effect for human's nutrition and health.
\end{abstract}

Keywords: Goats; Flaxseed; Saturated fatty acids; Unsaturated fatty acids.

\section{INTRODUCTION}

Goats are reared worldwide for its performance, durability and excellent ability to adapt to demanding conditions. Their milk has an extra special dietary and sensory properties, for which it is prized in many countries. Goats milk was the first animal milk used in human nutrition where still plays an important role (Vejcik and Kral, 1998). It is very valuable and desired food for their unique composition and high digestibility.

Milk goats is of particular nutritional and economic importance in many parts of the world. It is primarily used for the production of traditional cheeses, yoghurt and ice cream. The composition of milk is one of major factor determining its value in the market. The nutritive value and technological properties of milk are largely influenced by its composition (MorandFehr et al., 2007).

Protein of goat milk are more digestible, and their basic amino acids are absorbed easily in comparison to cow milk (Ceballos et al., 2009), also goat milk contains six out of ten essential amino acids in higher amounts (Haenlein, 2004). In addition, goat milk contain casein only in small amount and for this reason is suitable for people suffering for casein allergy (Raynal-Ljutovac et al., 2008).

Generally, milk fat has been criticized for its high content of saturated fatty acids, which contribute to development of hypercholesterimia, atherosclerosis and other cardiovascular health problems (Noakes et al., 1996). However, the high fat content in goat milk might limit the demand for milk and milk product by health-conscious consumers. Ruminant milk contains relatively higher amount of saturated fats than most oils of plant origin. The consumption of saturated fats is often associated with health disorders in man, such as coronary heart disease (Pfeuffer, 2001). Therefore, efforts have been directed to manipulate fatty acid (FA) composition of ruminant milk. In this regard, the influence of changes in diet composition in milk FA profile of goats has been extensively studied (Nudda et al., 2003; Chilard and Feraly, 2004). Numerous 
studies using dietary modification have been conducted to manipulate milk fatty acid composition in order to reduce concentrations of saturated fatty acids and increase the concentrations of polyunsaturated fatty acids (PUFA). Increasing milk concentrations of specific health-promoting fatty acids, such as conjugated linoleic acid (CLA) and linolenic acid, is of particular interest because of their role in prevention of specific human health problems (Parodt, 1999). Feeding oilseeds and vegetable oils is an effective method to manipulate fatty acid composition of goat's milk (Mir et al., 1999) by reducing saturated: unsaturated fatty acid ratio of the milk.

Flaxseed (Linum usitatissimum) is a rich source of $\alpha$-linolenic acid (ALA), constituting nearly $55 \%$ of total oil, this percentage is 5.5 times more than the sources containing the highest ALA (Bloedon and Szapary, 2004). Feeding flaxseed to dairy cows reduced the concentrations of short-chine and saturated fatty acids and increased concentration of long-chine fatty acids and PUFA (Goodridge et al., 2001; Petit, 2002 and Mustafa et al., 2003). Few data are available on performance of lacting goats fed on flaxseed oil rich in PUFA.

Therefore, the objective of the present study was to determine the effects of feeding different levels of flaxseed to lacting goats on milk production, composition and fatty acids profile.

\section{MATERIALS AND METHODS}

\section{Materials:}

\section{Flaxseed oil}

Cold pressed Flaxseed oil was obtained from Extract and Press Oil Unit, National Research Center, Dokki, Cairo, Egypt.

\section{Experimental animals}

\section{Goats}

Twenty-four Zaraibi goats at the last $6^{\text {th }}$ weeks of gestation aged 4-5 years and weighting $38 \pm 4 \mathrm{~kg}$. had the third parity of lactation were used in the present study. The goats were obtained from Sakha Experimental Research Station belonging to Animal Production Research Institute (APRI), Ministry of Agriculture, Egypt.

\section{Basal diet}

Goats basal diet consisted of pelleted concentrate feed mixture $(14 \% \mathrm{CP}$ and $60 \%$ TDN) plus $3 \mathrm{~kg}$ Egyptian clover (Trifolium Alexanrium) / h/ day and bean straw ad lib

The concentrates consisted of $25 \%$ undecorticated cotton seed meal, 35\% wheat bran, $30 \%$ corn, $3 \%$ rice bran $3 \%$ molasses, $2 \%$ limestone, $1 \%$ urea and $1 \%$ salt $(\mathrm{NaCl})$.

\section{Methods}

\section{Feeding experiment of goats}

Twenty-four lactating Zaraibi goats were randomly divided into four equal groups, according to live body weight, age and parity of lactation.

Group (1) served as control, nil flaxseed oil supplements.

Group (2) administrated $10 \mathrm{~mL}$ flaxseed oil/head/day.

Group (3) administrated $20 \mathrm{~mL}$ flaxseed oil/head/day.

Group (4) administrated $30 \mathrm{~mL}$ flaxseed oil/head/day.

Diets offered at two times, $9.00 \mathrm{am}$ and $3.00 \mathrm{pm}$ daily, requirements during pregnancy and lactation, according to (NRC recommendations, 2001), while fresh drinking water was freely available all over the day time.

\section{Milk yields and samples}

The technique of hand milking was used to stimulate milk yield. Goats have been milked twice daily every week by milking one teat, while the kid suckles the other one. Total milk yield/goat $=($ Total milk yield in one teat $x 2$ in the morning) + (Total milk yield in one teat $x 2$ in the afternoon).

A composite sample ( $10 \%$ of total daily milk yield) was immediately collected for chemical analysis.

\section{Chemical analysis}

\section{Milk fat and Protein contents}

Fat and total nitrogen contents were determined as described by (Ling, 1963).

\section{Total solids (TS) and ash contents}

Total solids and ash contents were determined according to (A.O.A.C, 2012). 


\section{Lactose content}

Lactose content was calculated by the difference between total solids and (fat, protein and ash contents).

\section{Determination of fatty acids profile}

The fatty acids profile of flaxseed oil and milk samples were determined as methyl ester by gas liquid chromatography according to the A.O.A.C. (2011).

\section{RESULTS AND DISCUSSION}

The present study was carried out with twenty-four lactating Zaraibi goats at the last $6^{\text {th }}$ weeks of gestation until 90 days after parturition, due to time of weaning their kids. Experimental animals were randomly divided into four equal groups, according to live body weight, age and parity of lactation.

However, this study aimed to define the effect of flaxseed oil supplementation (10, 20 and 30mL. flaxseed oil /head/day + basal diet) on milk production, milk composition and fatty acids profile.
Milk yield and milk composition of lactating goats at different treatments are presented in Table 1. From the data obtained it could be observed that the average values of milk yield increased in the experimental groups by 14.58, 18.75 and $26.04 \%$ for G1, G2 and G3 treatments, respectively, as compared with control. This finding may be due to higher ruminal volatile fatty acids (VFAs) concentration in rumen than control. Hence, total VFAs concentration in the rumen depends on nutrient digestibility, absorption rate, rumen $\mathrm{pH}$, as well as the microbial population in rumen and their activities. Also, Kholif et al. (2014) stated that the highest concentrations of VFAs lead to more efficient anaerobic fermentation, which might due to increase organic matter and fibers digestibility and led to improve milk yield of lactating goats. However, our results are in agreement with those reported by Zhang et al. (2006), Ingvortova et al. (2013), Kholif et al. (2015) and Morsy et al. (2015).

Table 1. Effect of flaxseed oil supplementation on milk composition and average of daily milk yield (g/head/day).

\begin{tabular}{lcccc}
\hline \multirow{2}{*}{$\begin{array}{c}\text { Stage } \\
\text { Overall means of: }\end{array}$} & Cont. & G1 & G2 & G3 \\
\cline { 2 - 5 } & 13.29 & 13.30 & 13.17 & 13.42 \\
\hline Total solids\% & 3.30 & 3.40 & 3.53 & 3.90 \\
Fat $\%$ & 3.51 & 3.54 & 3.69 & 3.56 \\
Protein\% & 5.72 & 5.64 & 5.21 & 5.26 \\
Lactose\% & 0.76 & 0.71 & 0.73 & 0.69 \\
Ash\% & & 1100 & 1140 & 1210 \\
$\quad \begin{array}{l}\text { Average of daily milk yield } \\
\text { (g/head/day) }\end{array}$ & 960 & & \\
\hline
\end{tabular}

Cont.: plain goat's milk., G1: milk from goats received 10mL flaxseed oil /day.

G2: milk from goats received 20mL flaxseed oil /day, G3: milk from goats received 30mL flaxseed oil /day

Results of chemical composition of goat's milk as affected by flaxseed oil supplementation are illustrated in Table 1. data obtained revealed that no pronounced effect of feeding flaxseed oil on TS\% of resultant milk in different treatments as compared with the control. Our results in agreement with those of Morsy et al. (2015).

Furthermore, milk fat percentage was higher for goats fed $30 \mathrm{~mL}$ flaxseed oil/day (G3) than those fed on $10 \mathrm{~mL}$ and $20 \mathrm{~mL}$ flaxseed oil or the control diet. Our results are consistent with other reports where milk fed percentage increased for goats fed supplemental fats (Mir et al., 1999; Zhang et al., 2006 and Morsy et al., 2015).

The higher milk fat levels in different treatments could related to more VFAs produced in rumen of goats as compared to control groups. Actually, milk fat synthesis known to involve the coordinated activity of several lipogenic enzymes, but PUFAs nutrition may regulate mammary lipoprotein lipase, acetyl-CoA carboxylase, fatty acid synthase and stearoyl-CoA desaturase, 
which considered a key to produce greater milk fat (Bernard et al., 2009).

In addition, milk protein percentage showed no remarkable effect by dietary treatments (Table 1), which is in agreement with other reports (Kitessa et al., 2003; Zang et al., 2006; Hassan et al., 2012 and Kholif et al., 2015 ). Our results, however, are different from Rotunno et al. (1998) and Casals et al. (1999) where a negative effect was found on milk protein percentage of goats. While, Morsy et al. (2015) defined no effects of sunflower oil addition to lactating Damascus goats' diets on milk protein as compared to control group). However, Wu and Huber (1994) mentioned that this statement may be attribute to a lake of increase in amino acids available to the mammary gland for protein synthesis as milk yield increase during fat supplementation.

Moreover, as shown from Table 1, there were no noticeable effect of flaxseed oil on milk lactose and ash contents in the treatment groups compared with control, where, the control group possessed the highest values, being $5.72 \%$ and $0.76 \%$ for lactose and ash contents respectively. The same trend of results was previously reported by Abdelhamid et al. (2013) for lactose content and Morsy et al. (2015) for ash content. In contrast, Morsy et al. (2015) reported that linseed oil supplementation caused significant and positive correlation coefficient between lactose production and oil addition to goat diets.

On the other hand, fatty acids profile of flaxseed oil was carried out and results obtained are listed in Table

(2).

Table 2. Fatty acids profile of flaxseed oil.

\begin{tabular}{|c|c|c|c|c|c|}
\hline Fatty acid & $\%$ & Fatty acid & $\%$ & Fatty acid & $\%$ \\
\hline C16:0 & 5.00 & $\mathrm{C} 18: 1 \omega 7$ & 1.00 & $\mathrm{C} 18: 3 \omega 4$ & 0.14 \\
\hline C18:0 & 3.90 & 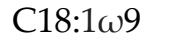 & 18.91 & 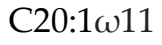 & 0.10 \\
\hline $\begin{array}{l}\text { C20:0 } \\
\text { TSFAs }\end{array}$ & $\begin{array}{l}0.12 \\
9.09\end{array}$ & 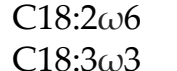 & $\begin{array}{l}14.83 \\
55.93\end{array}$ & TUFAs & 90.91 \\
\hline
\end{tabular}

TSFAs: Total saturated fatty acids, TUFAs: Total unsaturated fatty acids

From these results it could be noticed that, out of nine fatty acids detected, three SFAs and six UFAs. However, flaxseed oil had a high TUFAs content, being $90.91 \%$, while TSFAs possessed only $9.09 \%$ of the total fatty acids.

In addition, the two fatty acids (C16:0 and C18:0) were the highest SFAs 5.00 and $3.90 \%$, respectively, while for UFAs the highest values of 55.93, 18.91 and $14.83 \%$ were recorded for C18:3 $\omega 3$ ALA, C18:1 $\omega 9$

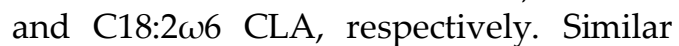
finding was previously reported by Oomah (2001), Daun et al. (2003) and WeeSim et al. (2007).

Furthermore, the overview of analysed fatty acids from goats' milk at different sampling periods are presented in Tables 3 and 4 .

From Table 3, it could be seen that the most abundant saturated fatty acids (SFAs) was palmitic acid (C16:0) followed by stearic acid (C18:0). Throughout lactation period, palmitic acid percentage for control treatment attained the highest level of SFAs in goats' milk samples varied from $25.97 \%$ to $34.38 \%$ of SFAs, with a mean value of $31.54 \%$, which represent $46.82 \%$ of TSFAs. In contrast, palmitic acid concentration was sharply reduced in all treatments supplemented with flaxseed oil and possessed lower values with an average of $22.02 \%$, this figure represent about $37.89 \%$ of TSFAs. However, these results were consist with those found by Gómez-cortes et al. (2009), Mele et al. (2011) and Gassi et al. (2012).

Contrarily to palmitic acid concentration, stearic acid values achieved an opposite trend, in which their mean value in control treatment was reduced to about $12.56 \%$ of SFAs, while flaxseed oil treatments had the highest average figure, actually $14.89 \%$ of SFAs throughout lactation period. These results were comparable to those reported by Gassi et al. (2012). 
Table 3. Effect of different treatments on milk saturated fatty acids profile (\%).

\begin{tabular}{lcccccccccccc}
\hline \multirow{2}{*}{ Items } & \multicolumn{4}{c}{$1^{\text {st }}$ month } & \multicolumn{1}{c}{ 2nd $^{\text {nd }}$ month } & \multicolumn{4}{c}{$3^{\text {rd } \text { month }}$} \\
\cline { 2 - 14 } & Cont & G1 & G2 & G3 & Cont & G1 & G2 & G3 & Cont & G1 & G2 & G3 \\
\hline C4:0 & 0.75 & 0.91 & 0.90 & 0.76 & 0.84 & 1.64 & 2.28 & 0.84 & 1.48 & 0.59 & 1.13 & 1.18 \\
C6:0 & 1.81 & 1.61 & 1.23 & 1.59 & 1.29 & 1.40 & 1.25 & 1.36 & 1.46 & 1.18 & 1.18 & 0.89 \\
C8:0 & 2.08 & 1.73 & 1.33 & 1.78 & 0.71 & 1.64 & 1.40 & 1.63 & 0.76 & 1.46 & 1.24 & 0.76 \\
C10:0 & 6.27 & 5.05 & 4.28 & 5.96 & 1.41 & 5.55 & 4.82 & 5.73 & 1.44 & 5.45 & 3.64 & 2.12 \\
C12:0 & 2.39 & 2.03 & 3.89 & 2.30 & 1.97 & 2.02 & 1.78 & 2.12 & 1.94 & 2.30 & 1.54 & 0.91 \\
C14:0 & 7.66 & 6.41 & 7.26 & 7.13 & 10.53 & 6.60 & 6.26 & 6.29 & 10.14 & 7.84 & 4.94 & 3.30 \\
C15:0 & 1.34 & 1.03 & 1.55 & 1.50 & 2.54 & 1.43 & 1.34 & 1.27 & 2.45 & 2.10 & 1.69 & 1.59 \\
C16:0 & 25.97 & 21.50 & 21.40 & 23.85 & 34.38 & 23.54 & 22.26 & 22.37 & 34.26 & 26.04 & 19.80 & 17.43 \\
C17:0 & 1.95 & 1.89 & 1.94 & 1.60 & 1.76 & 1.92 & 0.97 & 1.53 & 2.04 & 2.39 & 1.90 & 2.10 \\
C18:0 & 16.24 & 14.60 & 13.72 & 14.85 & 10.77 & 14.79 & 14.46 & 13.74 & 10.68 & 14.0 & 16.47 & 17.41 \\
C20:0 & 0.29 & 0.25 & 0.24 & 0.34 & 0.29 & 0.22 & 0.27 & 0.21 & 0.29 & 0.42 & 0.30 & 0.24 \\
TSFAs & 67.67 & 57.66 & 58.40 & 62.11 & 67.05 & 61.43 & 58.24 & 57.89 & 67.36 & 64.17 & 54.46 & 48.68 \\
\hline
\end{tabular}

Cont.: control goat's milk., G1: milk from goats received $10 \mathrm{~mL}$ flaxseed oil /day, G2: milk from goats received $20 \mathrm{~mL}$ flaxseed oil /day, TSFAs: total saturated fatty acids, G3: milk from goats received $30 \mathrm{~mL}$ flaxseed oil /day

From the previous results, it could be stated that the concentration of saturated fatty acids was reduced by flaxseed oil supplementation, where the mean value of the decreases attained $13.72 \%$, these decreases may be also influenced partially by lactation progress, where the mean value of SFAs concentration reduced from $59.39 \%$ in the first month of lactation to $55.77 \%$ at third month, in flaxseed oil treatments.

On the other hand, results presented in Table 4 and Figures 1-3 declared that flaxseed oil treatments showed pronounced increased effect on goats milk oleic, linoleic and ALA acids as compared to control. The same finding was previously reported by Luna et al. (2008), Atasoglu et al. (2009), Gassi et al. (2012), and Smiddy et al. (2012).

In addition, it was clear from the data obtained that the concentration of total unsaturated fatty acids (TUFAs) in flaxseed oil treatments were increased as compared with control treatment, where the increases \% ranged from $19.21 \%$ to $34.1 \%$ with a mean value of $28.32 \%$. Also, from the same table it was obvious that the major unsaturated fatty acids were oleic

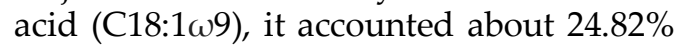
of the TUFAs of goats milk in all samples throughout lactation period.

Continuously, samples of treat. G3 ranked the highest levels of oleic acid in the third month of lactation actually $27.91 \%$, while control samples had the lowest value, being $22.49 \%$ in the second month of lactation. In this respect, Dhiman et al. (2000), and Loor and Herbein (2003) stated that linseed is rich in C18:1 and C18:3 fatty acids, which can contribute to increase C18:1 concentration in milk. C18:1 fatty acid is derived from the partial biohydrogenation of the $\mathrm{C} 18: 2$ and $\mathrm{C} 18: 3$ fatty acids that occurs in the rumen, by desaturation of stearic acid, which occurs in mammary gland due to the action of the enzyme 9-desaturase.

Furthermore, it was evident from the data presented in Table 4 and Figure 2 that flaxseed oil treatments recorded noticeable increased effect on goats milk linoleic acid (C18:2 n6) concentration as compared with control treatment. However, it could be gathered from the same table and Figure 3 that $\alpha$-linolenic acid (ALA) concentrations achieved greatly affect by flaxseed oil supplementation. ALA concentrations were varied from $0.20-3.04 \%$ in different tested goat milk samples, while kompan and komprej (2012) gave a narrow range, actually from 0.5 to $1.0 \%$. Moreover, the obtained data declared that, in the second month of lactation period, G3 treat. had the highest value of ALA, being 3.04\%, while control treat. ranked the lowest figure, actually $0.20 \%$. These results could be due to the fact that goats can successfully build linolenic fatty acid into milk fat when their diets supplemented with flaxseed oil which contain high amount of ALA $(55.93 \%)$ as shown in Table 2. However, similar results have been previously reported by Luna et al. (2008), Zhang et al. (2006), and Gassi et al. (2012). 
Table 4. Effect of different treatments on milk unsaturated fatty acids profile (\%).

\begin{tabular}{|c|c|c|c|c|c|c|c|c|c|c|c|c|}
\hline \multirow{2}{*}{ Items } & \multicolumn{4}{|c|}{$1^{\text {st }}$ month } & \multicolumn{4}{|c|}{$2^{\text {nd }}$ month } & \multicolumn{4}{|c|}{$3^{\text {rd }}$ month } \\
\hline & Cont & G1 & G2 & G3 & Cont & G1 & G2 & G3 & Cont & G1 & G2 & G3 \\
\hline C14:1 $\omega 5$ & ND & ND & ND & ND & 0.81 & ND & 0.25 & ND & 0.78 & ND & ND & ND \\
\hline C16:1 $\omega 9$ & 0.31 & 0.26 & 0.20 & 0.27 & 0.32 & 0.33 & 0.38 & 0.28 & 0.32 & 0.60 & 0.30 & 0.34 \\
\hline C16:1 $\omega 7$ & 0.76 & 0.77 & 0.72 & 1.10 & 2.45 & 0.83 & 1.04 & 0.90 & 2.57 & 1.06 & 1.10 & 1.25 \\
\hline $\mathrm{C} 16: 3 \omega 4$ & 0.31 & 0.31 & 0.26 & 0.24 & 0.33 & 0.27 & 0.24 & 0.18 & ND & 0.38 & 0.27 & 0.18 \\
\hline C18:1 $\omega 9$ & 22.67 & 24.79 & 26.60 & 22.88 & 22.49 & 24.27 & 27.40 & 22.69 & 23.41 & 26.13 & 26.58 & 27.91 \\
\hline $\mathrm{C} 18: 1 \omega 7$ & 2.48 & 3.43 & 4.21 & 3.59 & 2.83 & 4.55 & 1.70 & 4.57 & 2.87 & 2.40 & 7.40 & 8.67 \\
\hline C18:1 $\omega 5$ & 0.77 & 1.10 & 1.11 & 1.18 & 0.46 & 1.72 & 0.64 & 1.60 & 0.42 & 0.69 & 1.95 & 2.74 \\
\hline $\mathrm{C} 18: 2 \omega 5$ & 0.16 & 0.29 & 0.25 & 0.26 & 0.29 & 0.63 & 0.66 & 0.60 & ND & 0.35 & 0.44 & 0.75 \\
\hline $\mathrm{C} 18: 2 \omega 7$ & 0.17 & 0.24 & 0.24 & 0.31 & ND & ND & 3.42 & ND & ND & ND & 0.28 & ND \\
\hline C18:2 $\omega 6$ & 3.25 & 8.40 & 5.08 & 3.81 & 1.20 & 3.26 & 1.36 & 4.00 & 1.11 & 3.11 & 3.55 & 4.18 \\
\hline $\mathrm{C} 18: 2 \omega 4$ & 0.23 & 0.40 & 0.66 & 1.23 & 0.27 & 0.83 & 0.14 & 1.90 & 0.23 & ND & 1.01 & 1.87 \\
\hline $\mathrm{C} 18: 3 \omega 6$ & 0.16 & 1.48 & 0.16 & 0.17 & 0.15 & ND & ND & ND & ND & 0.20 & 0.20 & 0.18 \\
\hline $\mathrm{C} 18: 3 \omega 4$ & 0.65 & ND & 1.31 & 1.41 & 0.22 & ND & 2.66 & ND & ND & ND & ND & ND \\
\hline $\mathrm{C} 18: 3 \omega 3$ & 0.41 & 0.64 & 0.80 & 1.44 & 0.20 & 1.13 & 1.39 & 3.04 & 0.21 & 0.23 & 0.46 & 0.74 \\
\hline $\mathrm{C} 18: 4 \omega 3$ & ND & ND & ND & ND & 0.74 & 0.75 & 0.13 & 1.50 & 0.72 & 0.47 & 1.75 & 2.13 \\
\hline $\mathrm{C} 18: 4 \omega 1$ & ND & ND & ND & ND & ND & ND & 0.24 & 0.19 & ND & ND & ND & ND \\
\hline 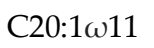 & ND & ND & ND & ND & 0.19 & ND & ND & 0.49 & ND & ND & 0.25 & 0.38 \\
\hline C20:4 $\omega 6$ & ND & ND & ND & ND & ND & ND & 0.11 & ND & ND & 0.21 & ND & ND \\
\hline TUFAs & 32.33 & 42.34 & 41.60 & 37.89 & 32.95 & 38.57 & 41.76 & 42.11 & 32.64 & 35.83 & 45.54 & 51.32 \\
\hline
\end{tabular}

Cont.: control goat's milk, G1: milk from goats received $10 \mathrm{~mL}$ flaxseed oil /day.

G2: milk from goats received $20 \mathrm{~mL}$ flaxseed oil /day, TUFAs: total unsaturated fatty acids.

G3: milk from goats received $30 \mathrm{~mL}$ flaxseed oil /day, ND: not detected

The comparation of fatty acids content between control and experimental group, divided according to chain length was carried out. Fatty acids were divided to short chain fatty acids (SCFA) from C4 to
C10, medium chain fatty acids (MCFA) from $\mathrm{C} 12-\mathrm{C} 16$ and long chain fatty acids (LCFA) from C18-C20. Results obtained are illustrated in Table 5.

Table 5. Overview of fatty acids divided according to chain length.

\begin{tabular}{lcccccccccccc}
\hline \multirow{2}{*}{ Items } & \multicolumn{4}{c}{ 1st month } & \multicolumn{4}{c}{ 2nd month } & \multicolumn{4}{c}{ 3rd month } \\
\cline { 2 - 13 } & Cont. & G1 & G2 & G3 & Cont. & G1 & G2 & G3 & Cont. & G1 & G2 & G3 \\
\hline SCFAs & 10.9 & 9.3 & 7.74 & 10.1 & 4.25 & 10.2 & 9.75 & 9.56 & 5.14 & 8.68 & 7.19 & 4.95 \\
MCFAs & 40.7 & 34.2 & 37.2 & 38 & 55.1 & 36.9 & 34.5 & 34.9 & 54.5 & 42.7 & 31.5 & 27.1 \\
LCFAs & 47.5 & 55.6 & 54.4 & 51.5 & 40.1 & 52.7 & 54.6 & 54.5 & 39.9 & 48.2 & 60.6 & 67.2 \\
\hline
\end{tabular}

Cont.: control goat's milk, G1: milk from goats received $10 \mathrm{~mL}$ flaxseed oil /day. G2: milk from goats received $20 \mathrm{~mL}$ flaxseed oil /day, G3: milk from goats received $30 \mathrm{~mL}$ flaxseed oil /daySCFAs: short chain fatty acids, MCFAs: medium chain fatty acids, LCFAs: long chain fatty acids.

From data obtained, it could be observed that fatty acid composition of milk fat was markedly altered by dietary treatments. Milk fat from goats fed on flaxseed oil had lower concentrations of short-chain fatty acids (SCFAs) and higher concentrations of long-chain fatty acids. The most pronounced impact was noted at the highest level of flaxseed oil supplementation $(30 \mathrm{~mL}$. flaxseed /head /day). The obtained values of SCFAs and LCFAs throughout lactation period "three months" were 10.1 and 51.5 in the first month, while in the third month were 4.95 and 67.2. The same trend of result was previously reported by Zhang et al. (2006).

Also, it was evident from the same table that control group possessed the highest level of MCFAs throughout lactation period with a mean value of $50.1 \%$, while flaxseed oil supplementation reduced this figure to about $35.22 \%$. In this respect, Bauman and Griinari (2003) stated that this reduction is likely the results of the negative effect of fat supplementation on the de novo synthesis of milk fat.

Furthermore, an opposite trend was recorded for LCFAs concentrations, however, flaxseed oil supplementation leads to a noticeable increase in LCFAs 
concentrations, these increases could be also influenced partially by progress of lactation, where the mean value of LCFAs increased from $53.83 \%$ in the first month to about $58.67 \%$ in the third month of lactation, while the increases values varied from 13.33 to $47.04 \%$ in flaxseed oil treatments as compared to control. In this connection, Zhang et al. (2006) reported that flaxseed oil is rich source of C18:0, C18:1 and C18:3 fatty acids which likely accounted for the increased concentrations of LCFAs in the milk of goats fed on the flaxseed oil diet.

However, our results are in agreement with those reported by Caroprese et al. ( 2010) and Ingovortova et al. (2013).

Furthermore, the average value of fatty acids content in goat milk are listed in Table 6, and Figures (4-7). Results of saturated (SFA), mono-unsaturated (MUFA), poly-unsaturated (PUFA) and unsaturated (UFA) fatty acids between experimental and control group are compared.
It was obvious from data obtained that the concentration of saturated fatty acids was reduced by flaxseed oil supplementation.

The decrease of SFA content could be also influenced partially by progress of lactation. The same relationship was also recorded by Strzalkowska et al. (2009 and 2010).

As seen from Table 6 and Figure 4, total SFAs in goat milk fat varied from 48.68 to $67.67 \%$, where control group had the highest value of total SFAs, being $67.67 \%$ in the first month of lactation period, while G3 group ranked the least figure, actually $48.68 \%$ in the third month of lactation.

Contrarily to SFAs, unsaturated fatty acids (UFAs) achieved an opposite trend, in which their values were markedly increased throughout lactation period and possessed the highest mean value of $35.51 \%$ in the third month of lactation as compared with control (Figure 5).

Table 6. Effect of different treatments on fatty acids content in milk fat.

\begin{tabular}{lcccccccccccc}
\hline \multirow{2}{*}{ Items } & \multicolumn{4}{c}{ 1st month } & \multicolumn{4}{c}{ 2nd month } & \multicolumn{5}{c}{ 3rd month } \\
\cline { 2 - 13 } & Cont. & G1 & G2 & G3 & Cont. & G1 & G2 & G3 & Cont. & G1 & G2 & G3 \\
\hline SFAs & 67.67 & 57.66 & 58.4 & 62.11 & 67.05 & 61.43 & 58.24 & 57.89 & 67.36 & 64.17 & 54.46 & 48.68 \\
MUFAs & 26.99 & 30.58 & 32.84 & 29.02 & 29.55 & 31.7 & 31.41 & 30.53 & 30.37 & 30.88 & 37.58 & 41.29 \\
PUFAs & 5.34 & 11.76 & 8.76 & 8.87 & 3.4 & 6.87 & 10.35 & 11.41 & 2.27 & 4.95 & 7.96 & 10.03 \\
UFAs & 32.33 & 42.34 & 41.6 & 37.89 & 32.95 & 38.57 & 41.76 & 42.11 & 32.64 & 35.83 & 45.54 & 51.32 \\
\hline
\end{tabular}

Cont.: control goat's milk., G1: milk from goats received $10 \mathrm{~mL}$ flaxseed oil /day. G2: milk from goats received $20 \mathrm{~mL}$ flaxseed oil /day., G3: milk from goats received $30 \mathrm{~mL}$ flaxseed oil /day, SFAs: saturated fatty acids, MUFAs: mono unsaturated fatty acids PUFAs: poly unsaturated fatty acids.

Moreover, it was of interest to notice that flaxseed oil supplementation increased the concentration of either MUFAs or PUFAs in resultant milk (Figures 6 and 7) and increase was more pronounced in G3 group in the third month of lactation, where the mean value of increase attained 42.53 and $73.3 \%$ for MUFAs and PUFAs, respectively relative to control.

In addition, obtained data revealed that control group ranked the lowest levels of total UFAs throughout lactation period varied from 32.33 to $32.95 \%$ with a mean value of $32.64 \%$. However, finding are in complete agreement with previous reports of Ward et al. (2002); Petit et al. (2004); Zhang et al. (2006) and Kral (2010).
Generally, from the foregoing results, it could be pointed out that addition of flaxseed oil to goats' diet increased milk yield by, as well as reducing saturated fatty acids (SFAs) and increasing of unsaturated fatty acids (UFAs) content in milk. Also, a noticeable increase in CLA and ALA content in milk can also be achieved by flaxseed oil supplementation to goats' diet. Thus, increasing PUFAs content have a favorable effect on human health, however, a proper ratio of n-3/n- 6 acid group showed be maintained, with the maximum value being 1/5 (Samkova et al., 2012), and this lead to reduce the risk of cardiovascular diseases. 


\section{REFERENCES}

Abd-El-hamid, A.M, Ashmawy, T.A.M., Faten, F.A., Heba, A.E., 2013. Effect of dietary inclusion of whole sunflower seeds on feeding lactating Zaraibi goats: Milk production and composition as well as mammary gland histology and economic efficiency. Int. J. Biotechnol. Res., 1 (1), 6-19.

Ataşoğlu, C., Uysal-Pala, Ç., KaragülYüceer, Y., 2009. Changes in milk fatty acid composition of goats during lactation in a semi-intensive production system. Arch. Tierzucht, 52 (6), 627-636.

A.O.A.C., 2011. Official Methods of Analysis of AOAC International. 18 $8^{\text {th }}$ Ed Published by the AOAC. International (revised edition), Gaithersburg, Maryland, U.S.A.

A.O.A.C., 2012 Official Methods for Analysis 19th Ed No. 969.33 chapter 41, Gaithersburg, Maryland, U.S.A, p. 1920.

Bauman D.E., Griinari, J.M., 2003. Nutritional regulationof milk fat synthesis. Ann. Rev. Nutr., 23, 203-227.

Bernard, L., Bonnet, M., Leroux, C., Shingfield, K.J., Chilliard, Y., 2009. Effect of sunflower-seed oil and linseed oil on tissue lipid metabolism, gene expression, and milk fatty acid secretion in alpine goats fed maize silage-based diets. J. Dairy Sci., 92 (12), 6083-6094.

Bloedon, L.T., Szapary, P.O., 2004. Flaxseed and cardiovascular risk. Nutr. Rev., 62 (1), 18-27.

Caroprese, M., Marzano, A., Marino, R., Gliatta, G., Muscio, A., Sevi, A., 2010. Flaxseed supplementation improves fatty acid profile of cow milk. J. Dairy Sci., 93 (6), 2580-2588.

Casals, R., Caja, G., Such, X., Torre, C., Calsamiglia, S., 1999. Effects of calcium soaps and rumen undegradable protein on the milk production and composition of dairy ewes. J. Dairy Res., 66, 177-191

Ceballos, L.S., Morales, E.R., Martínez, L.P., Extremera, F.G., Sampelayo, M.R. S., 2009. Utilization of nitrogen and energy from diets containing protein and fat derived from either goat milk or cow milk. J. Dairy Res., 76 (4), 497504.
Chilliard, Y., Ferlay, A., 2004. Dietary lipids and forages interactions on cow and goat milk fatty acid composition and sensory properties. Reprod. Nutr. Dev., 44 (5), 467-492.

Daun, J.K., Barthet, V.J., Chornick, T.L., Duguid, S., 2003. Structure, composition, and variety development of flaxseed. In: Thompson, L.U., Cunnane, S.C. (Eds.), Flaxseed in Human Nutrition. AOCSPress, Champaign, USA, pp. 1-40.

Dhiman, T.R., Satter, L.D., Pariza, M.W., Galli, M.P., Albright, K., Tolosa, M.X., 2000. Conjugated linoleic acid (cla) content of milk from cows offered diets rich in linoleic and linolenic acid1. J. Dairy Sci., 83 (5), 1016-1027.

Gassi, J.Y., Thève, M., Beaucher, E., Camier, B., Maillard, M.B., Rousseau, F., Lopez, C., 2012. Soft goats' cheese enriched with polyunsaturated fatty acids by dietary supplementation: manufacture, physicochemical and sensory characterisation. Dairy Sci. Technol., 92 (5), 569-591.

Gómez-Cortés, P., Bach, A., Luna, P., Juárez, M., De la Fuente, M.A. 2009. Effects of extruded linseed supplementation on n-3 fatty acids and conjugated linoleic acid in milk and cheese from ewes. J. Dairy Sci., 92 (9), 4122-4134.

Goodridge, J., Ingalls, J.R., Crow, G.H., 2001. Transfer of omega-3 linolenic acid and linoleic acid to milk fat from flaxseed or Linola protected with formaldehyde. Can. J. Anim. Sci., 81 (4), 525-532.

Haenlein, G.F.W., 2004. Goat milk in human nutrition. Small Rum. Res., 51 (2), 155-163.

Hassan, T.M., Ibrahim, M., Itman, K. Abdel-Hai, I., 2012. Productive and reproductive performance of Zaraibi goats fed different types of protected fat. The 13th Science Conformance for Animal Nutrition Sharm El-Sheikh, 1417 February, 512-537.

Ingvortová, M., Čermák, B., Zábranský, L., Šimková, A., Švejdová, K., Šoch, M., 2013. Effects of flax seed supplementation to lactating goats on milk fatty acid content. Acta Univ. Cibiniensis. E Food Technol., 17 (2), 2128.

Kholif, A.E., Khattab, H.M., El-Shewy, A.A., Salem, A.Z.M., Kholif, A.M., El- 
Sayed, M.M., Mariezcurrena, M.D., 2014. Nutrient digestibility, ruminal fermentation activities, serum parameters and milk production and composition of lactating goats fed diets containing rice straw treated with Pleurotus ostreatus. Asian-Austral. J. Anim. Sci., 27 (3), 357-364.

Kholif, S.M., Morsy, T.A., Matloup, O.H., Ebeid, H.M., Kholif, A.M., 2015. Effects of crushed linseed or linseed oil supplementation on performance of dairy goats and fatty acid profile in milk. Life Sci. J., 12, 94-99.

Kitessa, S.M., Peake, D., Bencini, R., Williams, A.J., 2003. Fish oil metabolism in ruminants: III. Transfer of $n-3$ polyunsaturated fatty acids (PUFA) from tuna oil into sheep's milk. Anim. Feed Sci. Technol., 108 (1-4), 114.

Kompan, D., Komprej, A., 2012. The effect of fatty acids in goat milk on health. In: Chaiyabutred, N., (Ed.), Milk Production. An up to date Overview of Animal Nutrition, Management and Health IntechOpen Press, London, England, pp. 1-28.

Král, V., 2010. Ověření vlivu krmiv na př́ijem krmných dávek koz a složení jejich mléka. Diplomová práce, Zemědělská fakulta JU, Česká republika.

Ling, E.R., 1963. A Text Book of Dairy Chemistry Vol.2, 3rd Ed. Chapman and Hall, London.

Loor, J.J., Herbein, J.H., 2003. Reduced fatty acid synthesis and desaturation due to exogenous trans10, cis12-CLA in cows fed oleic or linoleic oil1. J. Dairy Sci., 86 (4), 1354-1369.

Luna, P., Bach, A., Juárez, M., de la Fuente, M.A., 2008. Influence of diets rich in flax seed and sunflower oil on the fatty acid composition of ewes' milk fat especially on the level of conjugated linoleic acid, n-3 and n-6 fatty acids. Int. Dairy J., 18 (1), 99-107.

Mele, M., Contarini, G., Cercaci, L., Serra, A., Buccioni, A., Povolo, M., Secchiari, P., 2011. Enrichment of Pecorino cheese with conjugated linoleic acid by feeding dairy ewes with extruded linseed: effect on fatty acid and triglycerides composition and on oxidative stability. Int. Dairy J., 21(5), 365-372.
Mir, Z., Goonewardene, L.A., Okine, E., Jaegar, S., Scheer, H.D., 1999. Effect of feeding canola oil on constituents, conjugated linoleic acid (CLA) and long chain fatty acids in goats milk. Small Rum. Res., 33, 137-143.

Morand-Fehr, P., Fedele, V., Decandia, M., Le Frileux, Y., 2007. Influence of farming and feeding systems on composition and quality of goat and sheep milk. Small Rum. Res., 68, 20-34.

Morsy, T.A., Kholif, S.M., Kholif, A.E., Matloup, O.H., Salem, A.Z.M., Elella, A.A., 2015. Influence of sunflower whole seeds or oil on ruminal fermentation, milk production, composition, and fatty acid profile in lactating goats. Asian-Austral. J. Anim. Sci., 28 (8), 1116-1122.

Mustafa, A.F., Chouinard, P.Y., Christensen, D.A., 2003. Effects of feeding micronised flaxseed on yield and composition of milk from Holstein cows. J. Sci. Food Agric., 83 (9), 920-926.

Noakes, M., Nstel, P.J., Clifton, P.M., 1996. Modifying the fatty acid profile of dairy products through feedlot technology lowers plasma cholesterol of humans consuming the products. Am. J. Clin. Nutr., 63, 42-46.

NRC, 2001. Nutrient Requirements of Dairy Cattle, seventh revised edition, Natl. Acad. Sci. Washington, DC, pp. 381.

Nudda, A., Mele, M., Battacone, G., Usai, M.G., Macciotta, N.P.P., 2003. Comparison of conjugated linoleic acid (CLA) content in milk of ewes and goats with the same dietary regimen. Ital. J. Anim. Sci., 2 (Sup. 1), 515-517.

Oomah, B.D., 2001. Flaxseed as a functional food source. J. Sci. Food Agric., 81 (9), 889-894.

Parodi, P.W., 1999. Conjugated linoleic acid and other anticarcinogenic agents of bovine milk fat. J. Dairy Sci., 82 (6), 1339-1349.

Petit, H.V., 2002. Digestion, milk production, milk composition, and blood composition of dairy cows fed whole flaxseed1. J. Dairy Sci., 85 (6), 1482-1490.

Petit, H.V., Germiquet, C., Lebel, D., 2004. Effect of feeding whole, unprocessed sunflower seeds and flaxseed on milk production, milk composition, and prostaglandin secretion in dairy cows1. J. Dairy Sci., 87 (11), 3889-3898. 
Pfeuffer M., 2001. Physiological effects of individual fatty acids in animals and human body, with particular attention to coronary heart disease risk modulation. Arch Tierz., 44, 89-98

Raynal-Ljutovac, K., Lagriffoul, G., Paccard, P., Guillet, I., Chilliard, Y., 2008. Composition of goat and sheep milk products: An update. Small Rum. Res., 79 (1), 57-72.

Rotunno, T., Sevi, A., Caterina, R.D., Muscio, A., 1998. Effects of graded levels of dietary rumen-protected fat on milk characteristics of Comisana ewes. Small Rum. Res. 30, 137-145.

Samková, E., Špička, J., Pešek, M., Pelikánová, T., Hanuš, O., 2012. Animal factors affecting fatty acid composition of cow milk fat: A review. South African J. Anim. Sci., 42 (2), 83-100.

Smiddy, M.A., Huppertz, T., van Ruth, S.M., 2012. Triacylglycerol and melting profiles of milk fat from several species. Int. Dairy J., 24 (2), 64-69.

Strzałkowska, N., Jóźwik, A., Bagnicka, E., Krzyżewski, J., Horbańczuk, K., Pyzel, B., Horbańczuk, J.O. 2009. Chemical composition, physical traits and fatty acid profile of goat milk as related to the stage of lactation. Anim. Sci. Pap. Rep., 27 (4), 311-320.

Strzałkowska, N., Jóźwik, A., Bagnicka, E., Krzyżewski, J., Horbańczuk, K., Pyzel,
B., Horbańczuk, J.O., 2010. The concentration of free fatty acids in goat milk as related to the stage of lactation, age and somatic cell count. Anim. Sci. Pap. Rep., 28 (4), 389-396.

Vejčík, A., Král, M., 1998. Chov ovcí a koz. 1. vyd. České Budějovice: Jihočeská univerzita v Českých Budějovicích Zemědělská fakulta, 1998. $145 \mathrm{~s}$.

Ward, A.T., Wittenberg, K.M., Przybylski, R., 2002. Bovine milk fatty acid profiles produced by feeding diets containing solin, flax and canola. J. Dairy Sci., 85 (5), 1191-1196.

Wee-Sim Choo, John, B., Jean-Pierre, D. 2007. Physicochemical and quality characteristics of cold-pressed flaxseed oils. J. Food Compos. Anal., 20, 202211.

Wu, Z., Huber, J.T., 1994. Relationship between dietary fat supplementation and protein concentration in lactating cows: A review. Livest. Prod. Sci., 39, 141-155.

Zhang, R., Mustafa, A.F., Zhao, X., 2006. Effects of flaxseed supplementation to lactating ewes on milk composition, cheese yield, and fatty acid composition of milk and cheese. Small Rum. Res., 63 (3), 233-241.

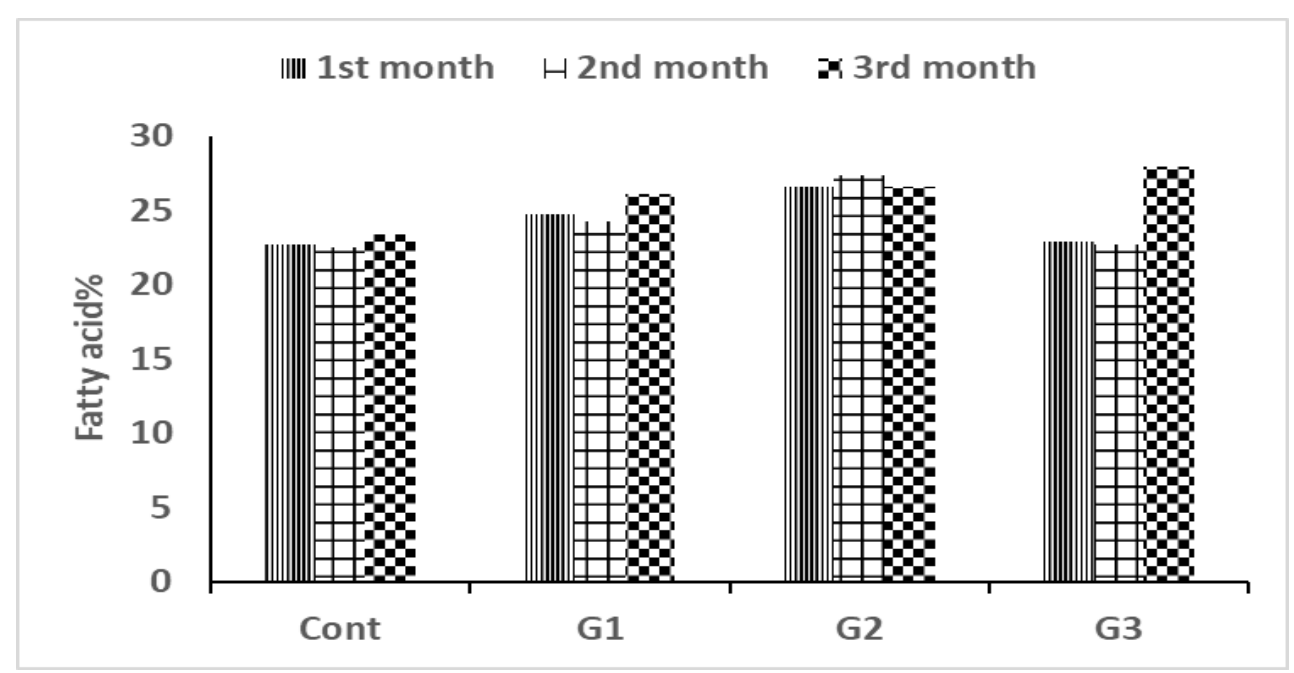

Figure 1. Effect of supplementation by flaxseed oil on C18:1 n9 goat milk fat content. 


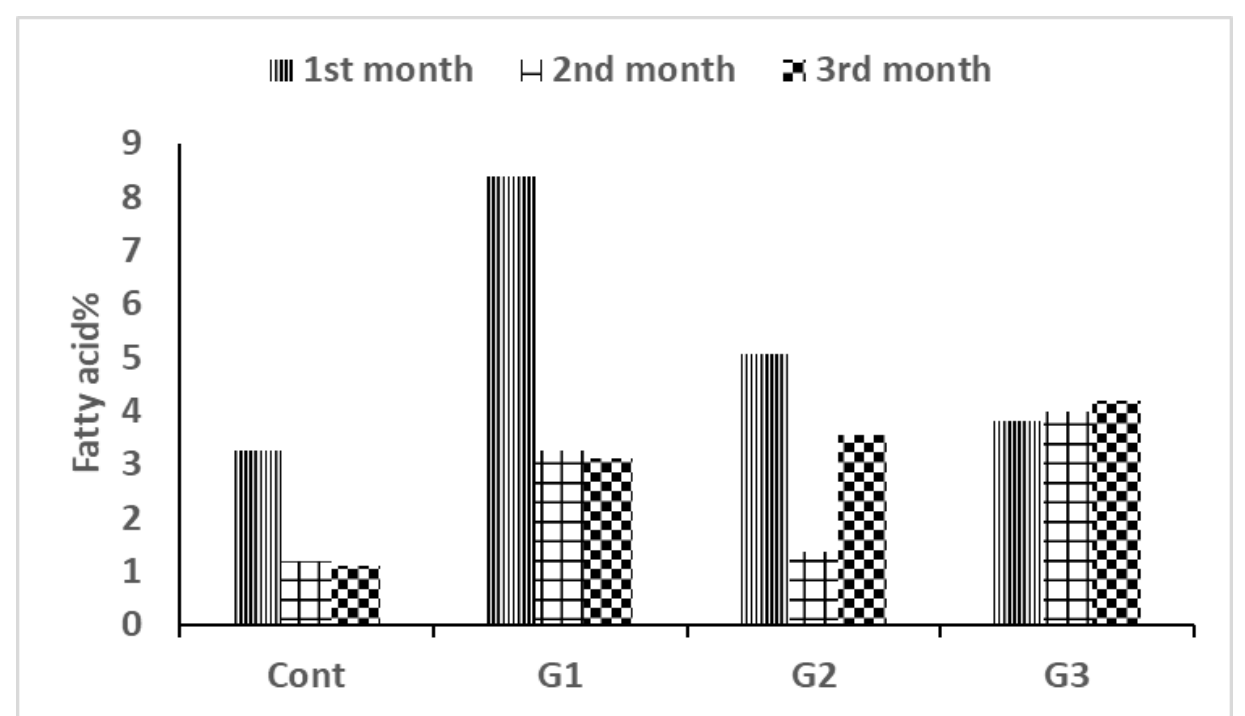

Figure 2. Effect of supplementation by flaxseed oil on C18:2n6 goat milk fat content.

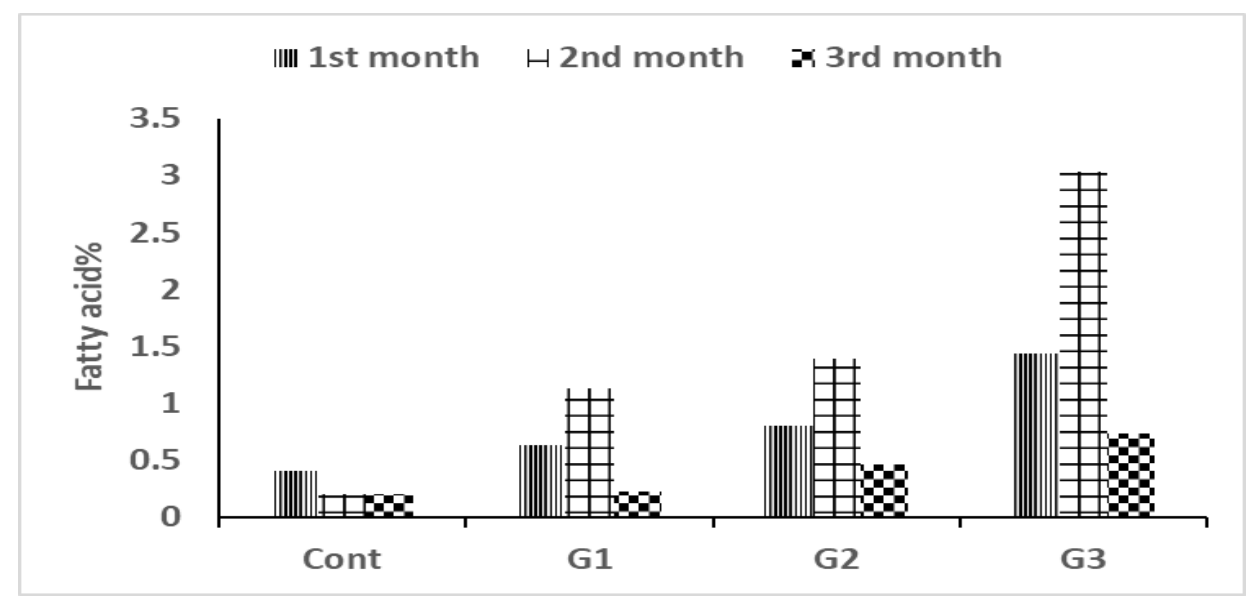

Figure 3. Effect of supplementation by flaxseed oil on ALA goat milk fat content.

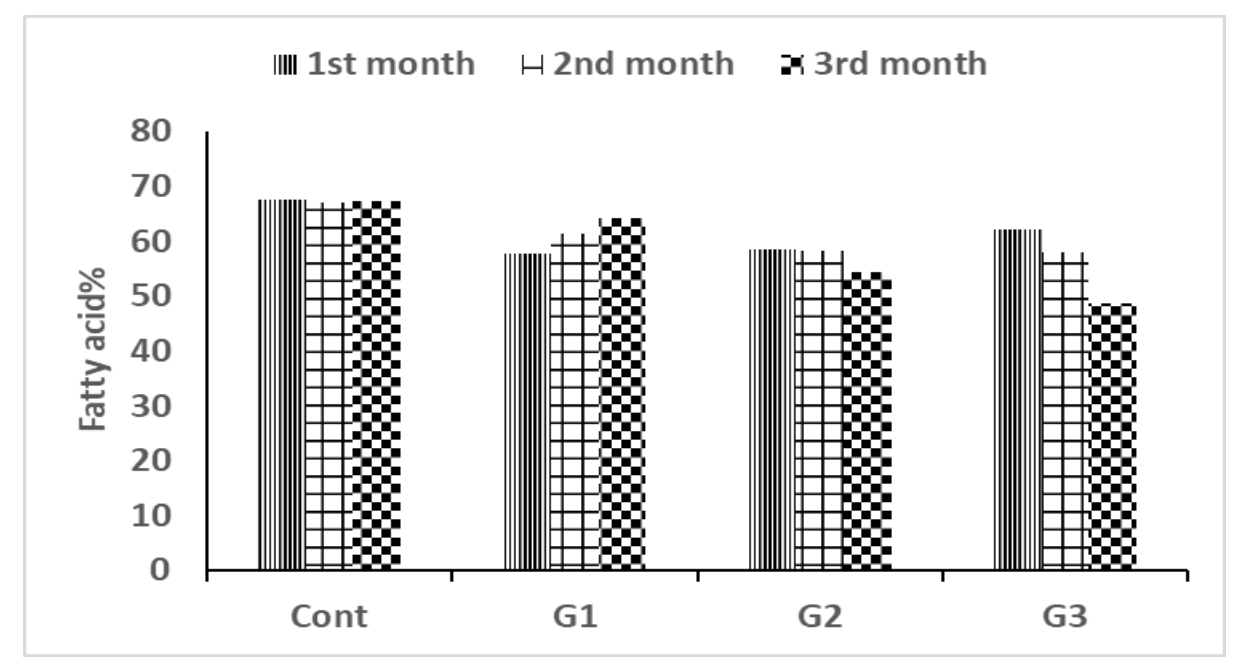

Figure 4. Effect of supplementation by flaxseed oil on SFAs in milk fat content. 


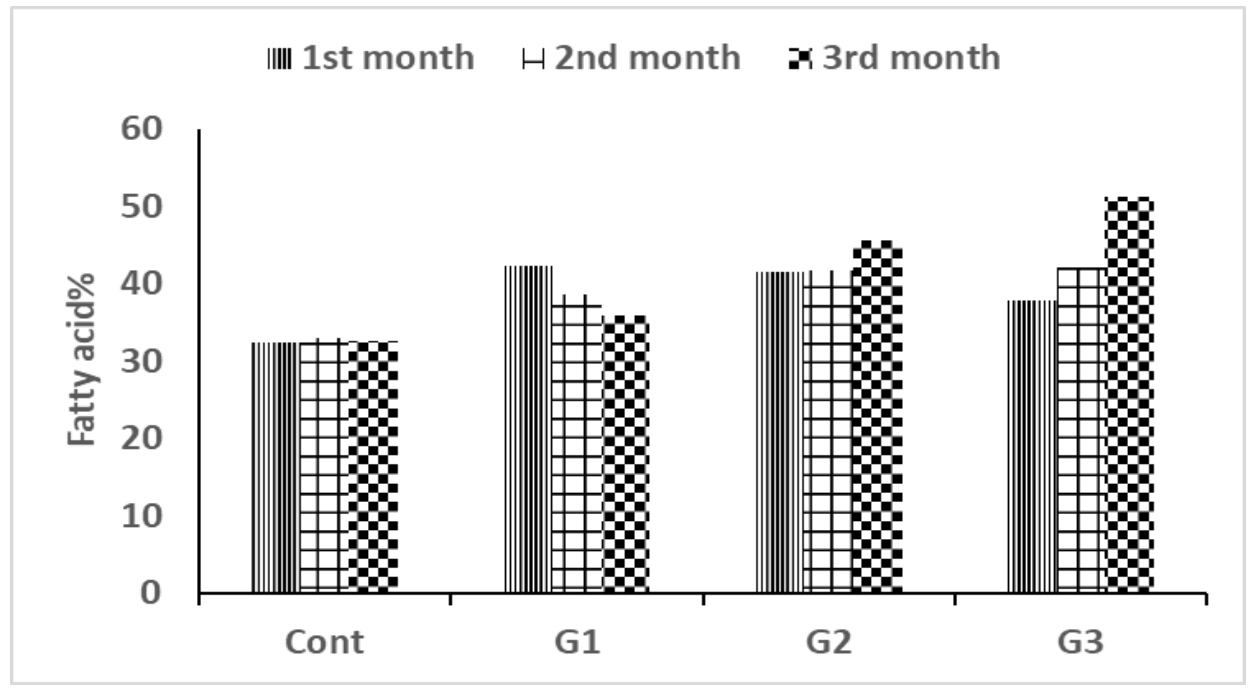

Figure 5. Effect of supplementation by flaxseed oil on UFAs in milk fat content.

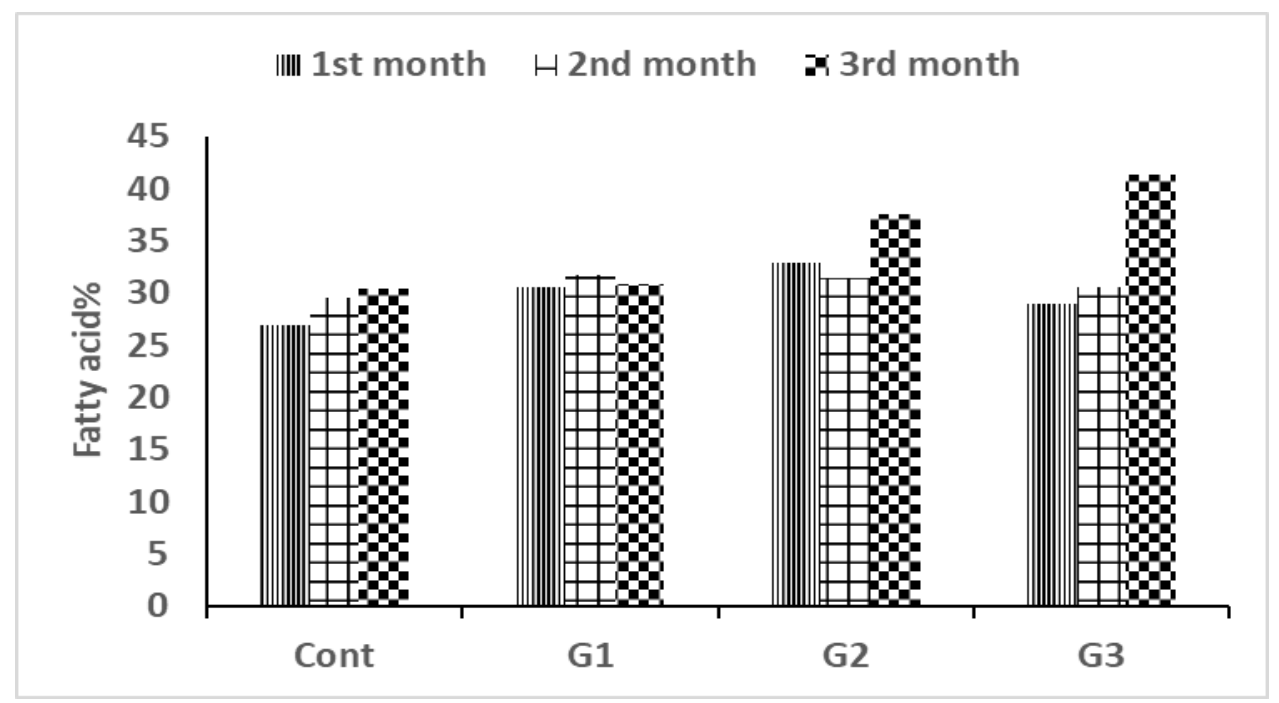

Figure 6. Effect of supplementation by flaxseed oil on MUFAs in milk fat content.

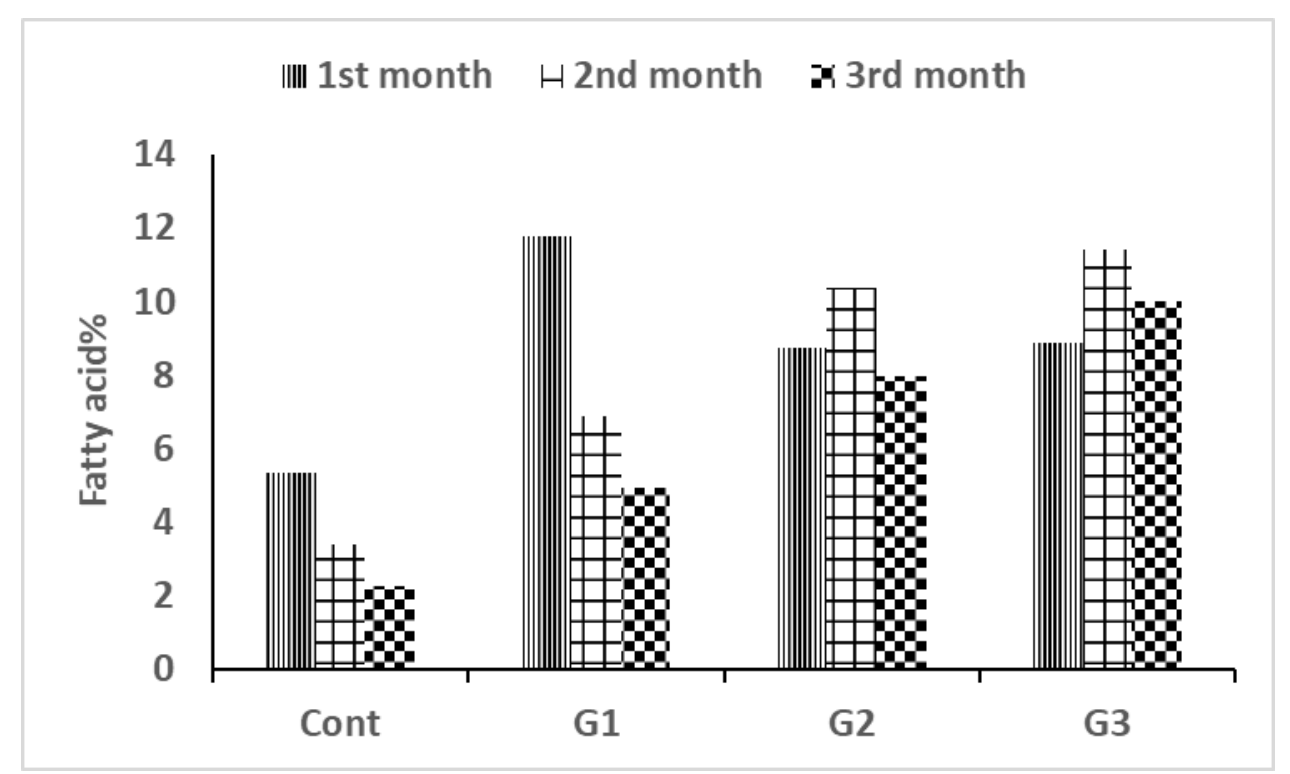

Figure 7. Effect of supplementation by flaxseed oil on PUFAs in milk fat content. 


\section{تأثير إضافة زيت بذرة الكنان إلى عليقه الماعز الملابة على إنتاجية اللبن، تريبه الكياوي ومتواه من الاحاض الدهنية}

$$
\begin{aligned}
& \text { منصور عبده علي 1"، محمود شعبان ثابت 1، عيد محمد إيراهيم² }
\end{aligned}
$$

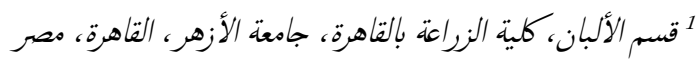

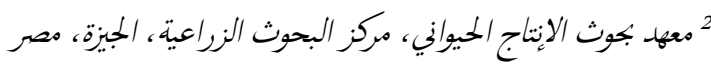

* البريد الإليكتروني للباحث الرئيس: DR.Mansourabdou@azhar.edu.eg

$$
\text { الملخص العربي }
$$

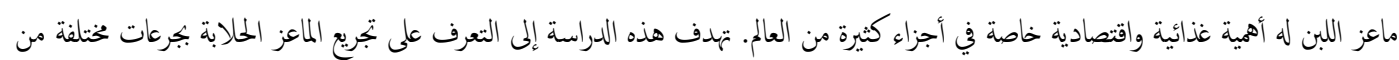

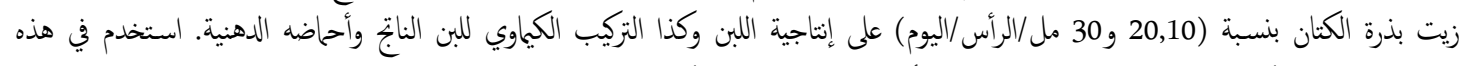

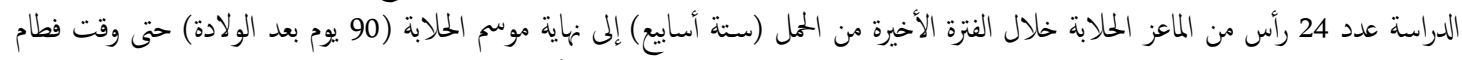

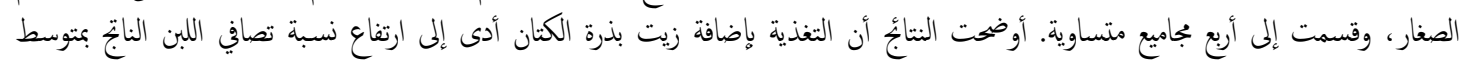

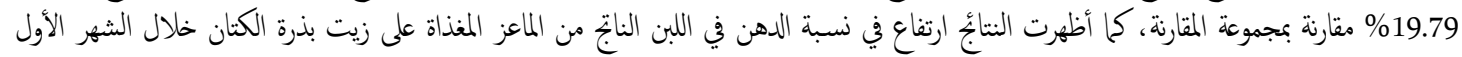

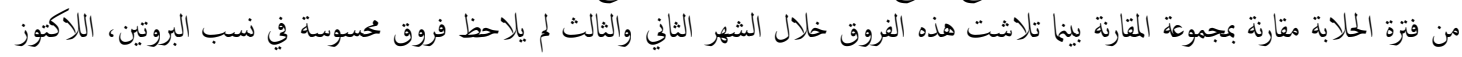

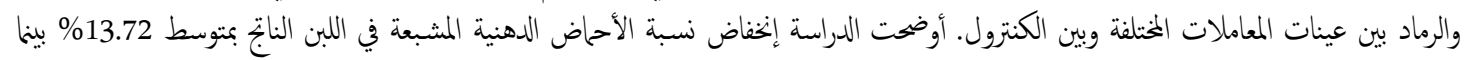

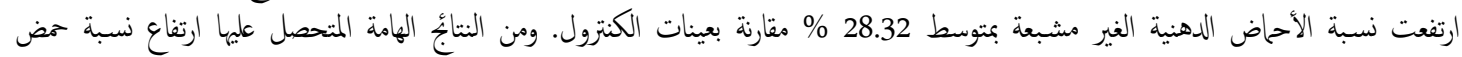

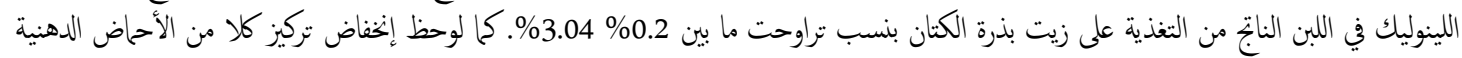

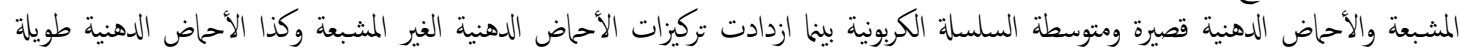

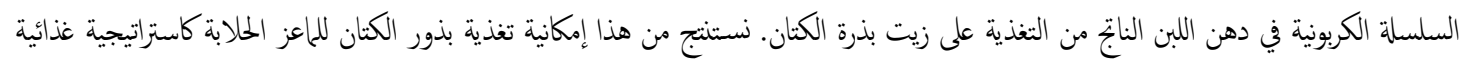

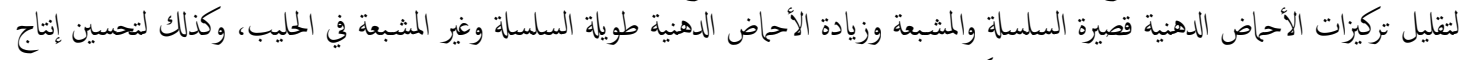

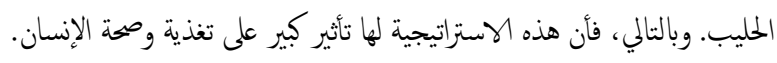

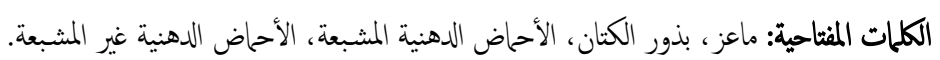

